\title{
Improving the Performances of Internet-Based Marketplace for Technology: A Korean Case Study
}

\author{
Jong Bok Park \\ Dept. of Venture \& Business, Gyeongnam National University of Science and Technology \\ 150 Chilam-Dong, Jinju, Gyeongnam, South Korea, 660-758 \\ jxpark@gntech.ac.kr
}

\begin{abstract}
Korean governments are experimenting with online approach for promoting technology transfer. Internet-based market for technology has limitations in completing transactions owing to characteristics intrinsic to technologies as subjects of transactions and allows the room for improving its role and function. This paper investigates the performance of the most representative marketplace for technology operating in Korea and explores its obstacles to satisfying the great expectations of stakeholders. The paper reports both quantitative and qualitative evidences through in-depth interview and focus group interview. The concluding remarks focus on management implications to enhance the performances of the Internet-based marketplace for technology.
\end{abstract}

Keywords: market for technology, technology transfer, Internet-based approach, technology commercialization.

\section{Introduction}

In Korea, the markets for technology have received great attention from the government and policy makers since the government enacted 'Korean Technology Transfer Promotion Act (KTTP Act)' in 2000. A series of pro-technology transfer programs have been launched in Korea on the basis of the KTTP Act, which resembles the U.S. Bayh-Dole Act of 1980 and the U.S. Stevenson-Wydler Technology Innovation Act of 1980. Because the market for technology was unfledged, the Korean government determined to develop the market for technology rapidly. Most of all, the government opened an Internet-based marketplace called 'National Technology Bank (NTB)' in 2000 based on the KTTP Act. ${ }^{1}$

Basically, markets for technology promote the diffusion and efficient use of existing technology and they can enhance the rate of technological advance by providing additional incentives to invest in R\&D (Arora et al., 2001). However, the markets for technology have remained imperfect in contrast to the markets for most products and services. As technological knowledge is usually commercialized by selling products

\footnotetext{
${ }^{1}$ In 2010, NTB was re-abbreviated as 'network for tech-biz.' The website of the NTB is www.ntb.kr.
} 
and services, the markets for technology are not common. At the same time, there are many imperfections in these markets, which result in high transaction costs.

Along with the 'information technology-based revolution', many practitioners and policy makers have assumed that Internet could help firms to overcome these market imperfections. In particular, Internet-based marketplaces for technology were expected to encourage inter-organizational technology transactions. A variety of intermediary companies, which are often backed by venture capital, have emerged to facilitate technology trading through Internet platforms. Prominent examples include Yet2.com, NineSigma, InnoCentive, and the Patent \& Licenses Exchange (Lichtenthaler \& Ernst, 2008).

By the way the NTB, that is, the most representative Internet-based marketplace for technology in Korea, doesn't seem to work effectively not only because of the characteristics intrinsic to technologies but also because of the failures of operation strategies. Very little is known about its success regarding the number of technology transactions that have originated from NTB, and hardly any information is unveiled by the Korean government that runs the marketplace. ${ }^{2}$ Therefore, it is needed to diagnose the current status of NTB and to enhance the performances of the Internetbased marketplace in order to meet the great expectations of stakeholders.

\section{Methodology}

\subsection{In-Depth Interview and Focus Group Interview}

In-depth interview was used to collect quantitative and qualitative data on NTB. The author asked several KIAT staffs in charge of NTB about their experiences and expectations, and the thoughts they have concerning NTB operations, processes, and outcomes as a result of their involvement in the Internet-based marketplace. Through the one-to-one interviews, comprehensive data on NTB were obtained.

Focus group interview was employed to identify obstacles to facilitating the NTB and to brainstorm the strategies for improving the performances of NTB. Focus group included eight professionals across the sectors of technology seller, buyer, intermediary, and investor. Questions were asked in an interactive group setting where participants were free to talk with other group members.

\subsection{Framework for Investigating Performances}

It is not easy to find previous research on the performances of Internet-based marketplace for technology to my knowledge. Park (2002) and Seo et al. (2003) propose the roles of cyber technology market focusing on online technomart services. Koh et al. (2009) suggests a conceptual model including the relationship between the online supporting services of technology intermediary and the performance of technology trading.

\footnotetext{
${ }^{2}$ NTB has been operated by the Korea Institute for Advancement of Technology (KIAT) on behalf of the Korean government.
} 
An Internet-based marketplace for technology is not only a cyber space where technology buyers and sellers meet each other, but also a one-stop total technology transaction support system that enables the systematic technology transaction to be accomplished on it (Park, 2002). In this paper, the performances of NTB were measured by primary performance and secondary performance (refer to Table 1). The primary performance implies the extent of vitalization of online market for technology, which can be classified into technology registration, technology evaluation, and technology marketing. The secondary performance tells how many technologies are licensed or sold online and/or offline after registration on Internet-based marketplace.

Table 1. Indicators measuring the performances of NTB

\begin{tabular}{|c|c|c|c|}
\hline \multicolumn{2}{|c|}{ Classification } & Indicator & Operational definition \\
\hline \multirow{5}{*}{$\begin{array}{c}\text { Primary } \\
\text { performance }\end{array}$} & \multirow{2}{*}{$\begin{array}{l}\text { Technology } \\
\text { registration }\end{array}$} & $\begin{array}{l}\text { Technology } \\
\text { supply }\end{array}$ & $\begin{array}{l}\text { - Number of technologies registered } \\
\text { for sale or licensing }\end{array}$ \\
\hline & & $\begin{array}{l}\text { Technology } \\
\text { demand }\end{array}$ & $\begin{array}{l}\text { - Number of technologies registered } \\
\text { that potential buyers demand }\end{array}$ \\
\hline & $\begin{array}{l}\text { Technology } \\
\text { evaluation }\end{array}$ & - & $\begin{array}{l}\text { - Incidences that customers utilize } \\
\text { the technology evaluation services } \\
\text { offered }\end{array}$ \\
\hline & \multirow[b]{2}{*}{$\begin{array}{l}\text { Technology } \\
\text { marketing }\end{array}$} & $\begin{array}{l}\text { Technology } \\
\text { promoting }\end{array}$ & $\begin{array}{l}\text { - Incidences that technologies are } \\
\text { promoted effectively }\end{array}$ \\
\hline & & Networking & $\begin{array}{l}\text { - Number of technologies which } \\
\text { information is shared by the other } \\
\text { Internet platforms }\end{array}$ \\
\hline $\begin{array}{l}\text { Secondary } \\
\text { performance }\end{array}$ & $\begin{array}{l}\text { Technology } \\
\text { transaction }\end{array}$ & - & $\begin{array}{l}\text { - Number of licensed or sold tech- } \\
\text { nologies among the ones registered }\end{array}$ \\
\hline
\end{tabular}

\section{Overview of NTB}

Several government ministries in Korea have been constructing their own online markets for technology competitively. NTB is the most representative market for technology, considering its biggest size in Korea, which is greater than five times that of the second largest 'IP-Mart' in terms of the number of technologies registered. ${ }^{3}$

NTB is an extended online platform for technology transaction, that is, a network for technology transfer and technology commercialization, which has been operated by KIAT in request of the Ministry of Knowledge Economy. NTB users can be supported by offline services as well as online ones.

Basically, NTB provides five types of services online, which consist of 'technology trading support service,' 'technology evaluation service,' 'technology news service,' 'technology consulting service,' and 'global business support service.' Technology

${ }^{3}$ IP-Mart is an abbreviation of Internet Patent Mart and it has been sponsored by the Korean Intellectual Property Office. As of 2010, NTB contains 78,011 cases of technologies supplied and 1,730 cases of technologies demanded. 
trading support service allows NTB users to search technologies of their interest by specific areas and technology sellers. Through technology evaluation service, NTB users can have technologies of their interest evaluated as well as compare other related evaluation reports provided by professional technology rating agencies.

In addition, technology news service enables NTB users to obtain various kinds of technology-related news focusing on recent trends of technological development and government funds available. NTB users can also take professional advice when they ask questions on technology transfer and commercialization through technology consulting service. Lastly, global business support service is specialized to provide NTB users with reliable information necessary to put themselves into global marketplaces, including the EU, the United States, China, Japan, and Southeast Asia.

In contrast, offline services of NTB have been offered through technology brokerage events. These are classified into domestic and international technology brokerage events. The former is held every week, and the latter is held about twice a year.

\section{Diagnosis of NTB}

\subsection{Investigation of NTB Performances}

With respect to primary performance of NTB, the performance of technology registration signifies how much database of supplied and demanded technologies is constructed in terms of its quantity. Technology supply of NTB has been conducted mainly by public sectors. In 2010 , there were few technologies that were supplied by private enterprises (62 cases by large companies; 5 cases by small and medium sized enterprises) and individuals (0 cases) while public research organizations (PROs) including universities and government laboratories registered 3,375 cases of technologies. Technologies on demand have also been of great scarcity except for a few of certified technology intermediaries. ${ }^{4}$ Only 37 cases of technologies were explicitly demanded on NTB through certified technology intermediaries in 2010. Thus, technology registration performance of NTB is unbalanced and dominated by public sectors despite of NTB's diverse supporting activities for vitalizing the marketplace for technology.

The performance of technology evaluation could be estimated by investigating how many times technology evaluation services are used. In detail, 'commercialization possibility evaluation service' (397 cases) and 'technology valuation service' (395 cases) were relatively more used than 'corporate technological capability evaluation service' (84 cases) and 'business plan preparing service' (105 cases) in 2010. However, most of certified technology intermediaries that are considered to be major beneficiaries have been employing their own evaluation solutions rather than technology evaluation services of NTB. This tells us that technology evaluation performance of NTB is a little bit measured excessively.

\footnotetext{
4 The KTTP Act stipulates that the government can certify technology intermediaries that meet some qualification criteria (Park, 2010).
} 
The performance of technology marketing implies how aggressively technologies on NTB are marketed. In 2010, NTB sent 1,638,419 newsletters to its users and about $44 \%$ of sent newsletters were received online. 226 cases of technologies on NTB were promoted through domestic and international technology brokerage events. However, its networking with other related Internet platforms or institutions, especially overseas institutions such as 'Asian and Pacific Center for Transfer of Technology', is not facilitated that much. Although NTB shares technology and market information with other Internet platforms, the amount of information shared is considerably limited owing to simple linkages.

Secondary performance of NTB could be represented by the performance of technology transaction, which is measured by licensed or sold technologies among the ones registered on NTB. The performance of technology transaction was on an increasing trend in the past three years (257 cases in 2007; 390 cases in 2008; 484 cases in 2009). Out of technologies transacted, the average cases of technologies traded through offline technology brokerage events were 62 during the past five years of 2005-2009. However, it is hard to measure how much NTB contributed to such technology transactions because technologies registered on NTB could be transferred through alternative channels without its direct assistance.

\subsection{Identification of Obstacles to Facilitating NTB}

In order to explore obstacles to facilitating NTB and analyze their causes, two steps of activities were performed. First, the obstacles were identified through the in-depth interview with KIAT staffs. According to the 'Survey on service utilization and user satisfaction on NTB' that KIAT administered in 2010, 'lack of public promotion' (27.5\%), 'low quality of information and service' $(25.5 \%)$, and 'inconvenient user interface' $(21.1 \%)$ were found to be three primary problems of NTB in terms of response rate. Second, the details and causes of these three problems were examined through the focus group interview.

'Lack of public promotion' includes confusion of the meaning on NTB, lack of promotion for success stories on technology transaction via NTB, and technology brokerage events undifferentiated from those of other agencies. This problem may be caused from the fact that NTB is somewhat ill-equipped and under-funded to accomplish its role and mission. Therefore, the majority of potential customers tend to have little interest in NTB while technology transfer managers in PROs are aware of its existence due to the legal duty of registering technologies developed in their organizations.

Next, 'low quality of information and service' implies technical knowledge-biased and/or outdated technology information, missing links of communication channels between technology sellers and potential buyers, low reliability of information linked to other Internet platforms, and low quality of technology consulting service. Several causes for this problem were posed in the focus group interview. Technology transfer managers in PROs were not strongly motivated to provide buyer-friendly technology information since they did not expect to be additionally rewarded for their efforts to register technologies (Choi, 2001). In addition, the ill-equipped and under-funded features of NTB were suggested as one of the major causes of this problem like that of 'lack of public promotion.' 
Lastly, 'inconvenient user interface' means heavy searching costs induced by technology seller-friendly arrangements of search results, limitation of the numbers and sizes of technology information files uploaded simultaneously, and uniform emailing service with less consideration of recipients. Being in consumers' shoes as well as listening to a variety of users' opinions is critical for improving user interface of NTB.

\section{Concluding Remarks: Management Implications}

In order to enhance the performances of the Internet-based marketplace for technology in Korea, the future managerial strategies for NTB need to focus on participant's incentives to use NTB and capability to accelerate commercialization.

With regard to participant's incentives, it is desirable that NTB users continue to revisit and utilize technology information and services. Thus, NTB needs to provide more application-oriented information, because technical knowledge-biased information is not easy for potential buyers to understand. Furthermore, the quality of information registered by sellers should be enhanced by controlling technology registration process and by monitoring the reliability of the information more tightly.

Second, the marketplace and users on NTB need to be segmented in order to differentiate technology markets and to customize various kinds of users. Without differentiating markets, technology sellers are not motivated to register their attractive technologies onto NTB. In particular, PROs are likely to supply valueless technologies, subject to the government regulation on the obligatory registration of technologies available for technology transfer. By customizing users, their satisfactions may be maximized and therefore they become loyal customers to NTB.

Third, the sector-wise networking communities should be organized and operated online and offline. A lot of opportunities for technology transaction and investment can be created and they can develop further into commercialization projects. It is recommended that the networking communities include investor such as venture capital as well as technology seller, buyer, and intermediary.

Concerning the capability to accelerate commercialization, NTB needs to be improved so that it enables the information and services to be utilized for commercialization. Therefore, NTB needs to provide reference information for technology transaction. In particular, reference information for pricing subject technologies is most demanded. Although NTB has been offering technology evaluation service and technology news service, the information from those services may not be enough to price potential technologies for trading. Thus, NTB may as well provide the primary statistics on technology transactions such as price, running royalty rate, and upfront fee by constructing database using the bi-annual technology transfer reports received from PROs.

Second, NTB needs to strengthen consultation services for technology transfer and commercialization. The current technology consulting services are offered only on the basis of online advising or commenting. It is not easy to find success stories or good experiences that customer benefited from the consultation service. Therefore, NTB may as well add consultation services on the basis of phone call or offline meeting in order to maximize the effect of consultation service. 
Third, NTB needs to link related government programs and policies to NTB in order to facilitate technology transfer and commercialization in there. KIAT, the operating agency of NTB, is planning and implementing a lot of government grant programs in the area of technology commercialization on behalf of the Korean government. Unfortunately, it seems that KIAT and the government regard NTB as just one of various programs they manage. Therefore, NTB needs to leverage its attractiveness by combining the other related grant programs in order to induce potential customers into NTB regime.

\section{References}

1. Arora, A., Fosfuri, A., Gambardella, A.: Markets for technology: The Economics of Innovation and Corporate Strategy. MIT Press, Cambridge (2001)

2. Choi, J.P.: Technology transfer with moral hazard. International Journal of Industrial Organization 19(1-2), 249-266 (2001)

3. Koh, J., Choi, S.-J., Lim, J.-D., Lee, G.-H.: An Exploratory Study on Online Service Factors Promoting Technology Trade. Korean Journal of Internet e-Commerce 9(3), 285-312 (2009) (in Korean)

4. Lichtenthaler, U., Ernst, H.: Innovation Intermediaries: Why Internet Marketplaces for Technology Have Not Yet Met the Expectations. Creativity and Innovation Management 17(1), 14-25 (2008)

5. Park, H.-W.: A study on improved roles of cyber Technology Market in Korea. Korean Journal of Internet e-Commerce 2(2), 143-165 (2002) (in Korean)

6. Park, J.-B.: Cultivating the technology transfer intermediary in Korea. KIET Industrial Economic Review 15(4), 40-54 (2010)

7. Seo, J., Lim, D., Jeong, H.: A review on the online technomart service and service strategy. Korean Journal of Internet e-Commerce 3(1), 95-117 (2003) (in Korean) 